\title{
STRATEGIC ELEMENTS OF ARAMAS
}

\author{
Partha Sarathi Mishra ${ }^{1}$, Ravindra Patnayaka ${ }^{2}$ \\ ${ }^{1}$ Assistant Professor, GITAM School of Architecture, GITAM University, Andhra Pradesh, India \\ ${ }^{2}$ Assistant Professor, GITAM School of Architecture, GITAM University, Andhra Pradesh, India
}

\begin{abstract}
This paper focuses on selection criteria for strategic location of Buddhist monasteries that influence their way of living. Many physical components influences the livability and in the creation of serene environments. Buddhist history depicts the way of life of Bhikshu-samuha relied upon concentrating and vitalizing their senses in isolation through Ayatana, thus inferring undisturbed abodes. So, Sangha - Dharma had its implications in forming their functional living spaces. So the site selection criteria for Aramas have specific considerations such as: Water as an element control the human emotions and regulates materialistic and non-materialistic aspects. Another element which is nature's canvas dealing with articulation of built spaces along with its magnificent scenic backdrop. Vista as an element gives us an idea of creating a platform for admiring the available panoramic view for regulating emotional and spiritual conscience. Further, Interaction spaces concentrate on creating a common platform for learning, performing prayers, meditation and social sharing. This paper explains these parameters of selection criteria for site selection through some case studies and visual analysis. Many points have been taken into consideration in concluding this paper as acclimatization of different landmasses during various seasons and the then conventional security systems.
\end{abstract}

Keywords: Buddhist Architecture, Aramas, Ayatana, Totlakonda, Ajanta cave, Nagarjunakonda

\section{INTRODUCTION}

Aramas are Buddhist settlements, where they usually have chaityas, stupas, viharas. These isolated clusters used to be located on strategic locations, camped permanently onto hillocks, looking over water-bodies or scenic landscapes, surprisingly serving as vistas, yet within proximity of few settlements of different order. The nature veiled undisturbed locations at higher altitudes creating a pleasurable and comfortable environment for the monks giving feasibility for performing their day to day activities effectively. The picturesque frame thus derived from the surroundings use to control the emotional domains of spiritual lot. The serene, calm locations away from the chaos, amidst dense nature fabric provided an undisturbed abode, reinforcing the concentration of the monks.

\section{CHRONOLOGY}

Buddhist Viharas/ Aramas used to be within as a part of settlements, as they were very much keen about "Sangha Dharma" during Hinayana, in Nalanda, Lumbini etc. Bodhisatvas, later initiated establishing Aaramas, onto isolated landmasses, amidst nature following "Vanaprastha - Dharma" [retiring into forest] [1], yet within immediate commutable proximity of settlements, so as to get prompt support in terms of food and finance.

According to the principle of Sunyata, Bhikshus preferred an isolated space for performing respective activities, where they could get a control over the respective senses, as per the principle of Ayatana [2]. A particular sect, "Bahirs" [one group of Buddhist monks] wanted to have their settlements over high raised platforms, implicating for the location of sites at higher altitudes [3].
Vajrayana is a period in which Buddhism had its heights of patronization across the globe and Asiatic countries in particular. In India, dynasties such as Guptas, Kushans, Satavahanas, followed Buddhism and contributed in creating built environments such as residential habitats, religious spaces, learning abodes, memorials etc. Buddhist Aramas played an important role in producing prophets, who preached Buddhism and in return enhanced the chances of trade and commerce with the European countries. The propagation of Buddhism in inlands and overseas both influences the strategic identification of sites along the water bodies, away from the civic centers and onto higher altitudes. Such settlements use to be the identification points for nautical commuters [4].

\section{WATER AS ELEMENT}

Water, being an active element, an excellent controller of human emotions, with respect to its physical attributes. Water regulates intangible aspects like visionary senses by its transparency, acquired colour, clarity, rippling movements etc. and audible senses by its scintillating sound, flowing rhythm. Water is sensitive towards tangible aspects like soothing breeze from the water bodies, and serene environmental implications [5].

Monasteries use to be acquainted with water bodies both still and flowing, effectively utilizing them for different conventional, functional aspects like pools, streams, springs as water resources, pits for bathing and soaking the veils [Figure 1A: Ramateerhham, Andhra Pradesh [6] \& 1F: Totlakonda, Andhra Pradesh [Photograph courtesy by the Authors]]. Waterfalls and ponds are as landscaping elements and focal elements within interaction spaces [Figure 1B: [7]] and moats for security reasons. 

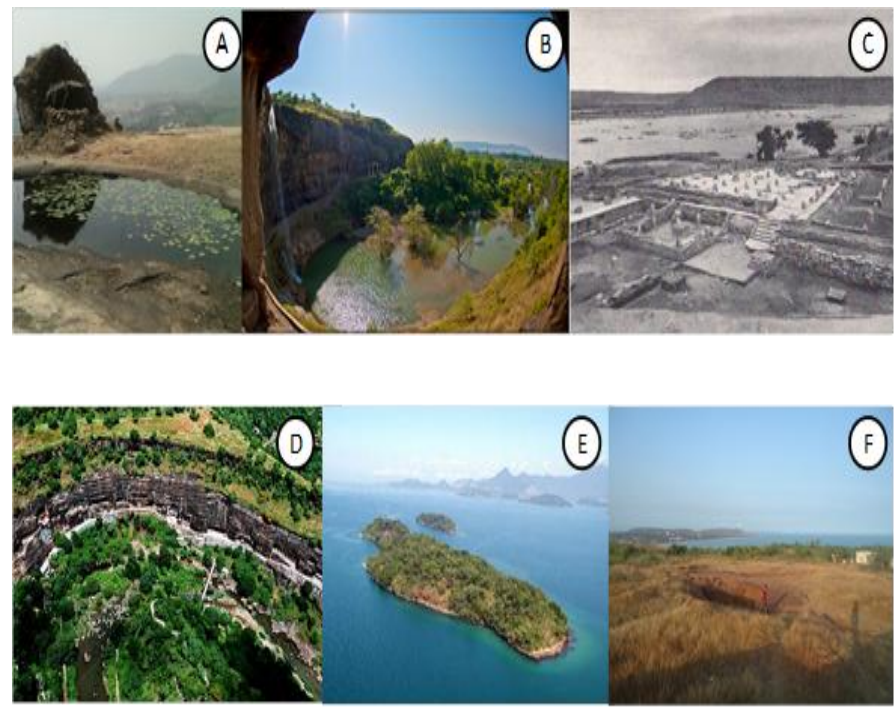

Fig -1: Water as Element

Majority of the earmarked vicinities used to be within the close proximity of rivers and seas for commuting, so as to develop and maintain relations with the remaining world. [Figure 1D: Ajnatha Caves [8]]. Travel records claims, the saga of monks in preaching, exploration and trade, in both inland and overseas, by making use of these water bodies [Figure 1E\&1F Nagarjuna Konda and Totlakonda, Andhra Pradesh] [4]. These spiritual hamlets use to ornament themselves with different forms of water bodies such as ponds, moats, waterfalls, pits etc. serving their respective attributes. Meditation platforms by the side of a flowing water-body use to enlighten the spirits of monks. [Figure 1C: Learning Platforms at Nagarjuna Konda, Andhra Pradesh [9]].

\section{NATURE'S CANVAS}

Aramas over citadels portrayed a picturesque panorama from higher abodes. The form, colour and texture of built elements use to borrow the available panorama as its beautiful backdrop, thus resulting in a nature's-scape [10]. [Figure 2A: Salihundam monastery with its waterscape backdrop contributed by River Vamsadhara, Andhra Pradesh [11] \& Figure 2D: Udayagiri, Orissa [12]].

The then monuments could able to get a picturesque backdrop with identifiable elements within close proximity and a carpet of distant atmospheric landscape, creating a perfect perspective on nature's canvas. [Figure 2B [13] \& 2C [8]: Composition of picture-scape with available nature and man-made elements as at Ajantha and Ellora vicinities]

\section{VISTA}

The location of site itself is able to create spectacular vistas. Vistas give feasibility of appreciating the derived nature scapes from different directions, at a higher altitude [Figure 3A: Kay gompa Monastery, Himachal Pradesh [14]]. The Panoramic Views thus perceived, prompted the scenic beauty that keeps emotions and spirits in pleasure. [Figure 3D: Meditation spaces at Ramateertham, Andhra Pradesh [15]]
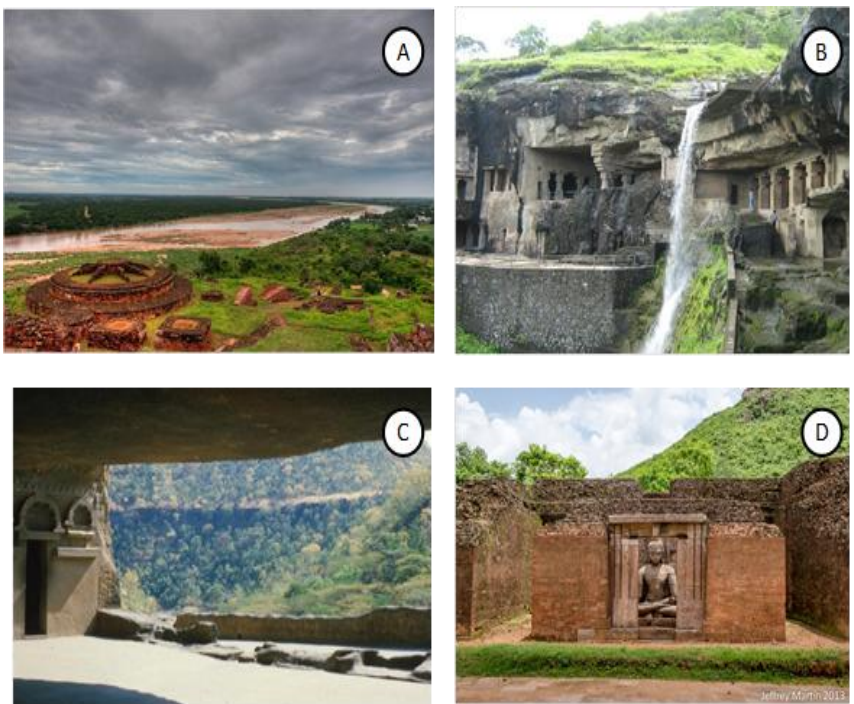

Fig -2: Nature's Canvas

The citadels use to provide a safe, undisturbed abode. These communities at higher altitudes possessed a proper watching vista providing a clear panorama of the surroundings such that one can monitor the happenings from the station. [Figure 3C: Ajantha Caves [8]] Vice-versa, these layouts at higher altitudes are strategically located such that they can be identified from distant places, for travellers such as Buddhist nomads in particular.[Figure 3B: Totlakonda, Andhra Pradesh [Photograph courtesy by the Authors]] Apart from this, these Aramas used to serve as transit halts for the Buddhist travellers passing by.

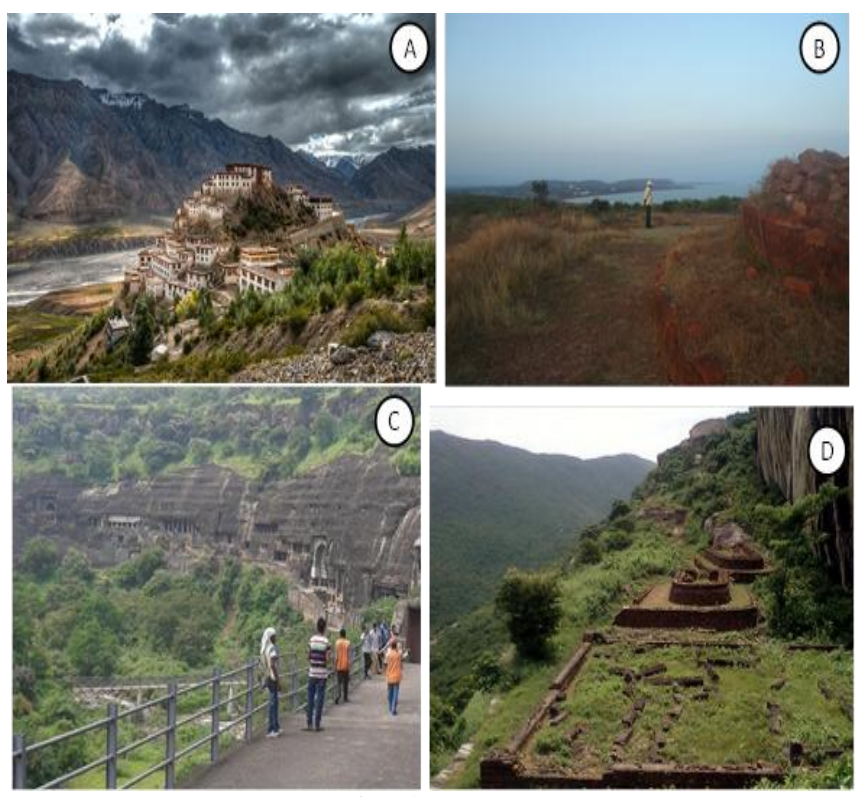

Fig -3: Vistas

\section{INTERACTION SPACES}

The Vicinities of Aramas were so serene and clam, that Bhikshu Samuha [the group of monks] could concentrate while learning, performing prayers and meditation. [Figure 4D Nagarjuna Konda, Andhra Pradesh] The Bhikshu Samuha Comprised of Acharyas and monks of all ages. The Learning environment used to rely upon both teaching and 
interactive sessions in both formal and informal spaces [Figure 4E Amphitheatre at Tadikonda, Andhra Pradesh [16]].

The Daily routine of Bhikshus also accommodated the informal gatherings, social sharing, individual isolation, community rituals [Figure 4B: Totlakonda [17]], forum for discussions etc. These self-centered communities sheltered "extrovertly introverts" in groups, constituted different hierarchical spaces such as private spaces for meditation, offering prayers and resting spaces, semi-open spaces for formal and informal gatherings and public spaces such as pavilions, gangways, and sharing platforms looking over extended nature scapes[Figure 4A \& 4C Ajanta caves [8]].
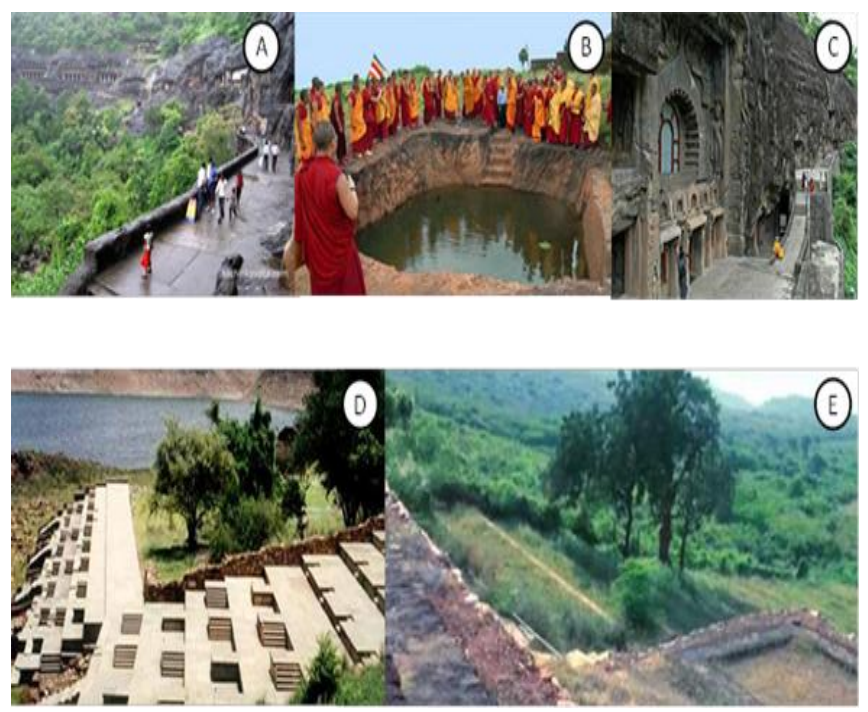

Fig -4: Interaction Spaces

\section{CONCLUSION}

Hence it can be concluded that many points can be considered as strategic elements for establishing Aramas such as - Water bodies seems to play an immense role for Buddhist settlements that used to regulate their total atmospheres, sprits, trade \& commerce etc. they make nature and built spaces articulated, resulted in the scenic beauty that can be transformed into a picturesque composition. Buddhists prefer higher altitude-places for their settlements as it provides a clear observational vista of their surroundings. Buddhist wants to have a calm serene interaction spaces for their learning, performing prayers, meditations and performing rituals. The micro climate at such locations is comparatively suitable, during all the seasons. The sustainability of their race for ages infers the possibility of having sound conventional management and security systems. Therefore the future researchers need to look into the settlement development criteria so as to establish their physical and socio-cultural relationships.

\section{REFERENCES}

[1]. Sharma, R. K. [1999], Institutions and Change. Indian Society, 28, 38-39.

[2]. Fisher, R. E. [1993], Buddhist Art and Architecture, Thames and Hudson Ltd.
[3]. Regmi, D. R. (1969). Ancient Nepal (3rd ed.). Calcutta: K L Mukhopadhyaya.

[4]. Rao, P. R. [1988], Indian Heritage and Culture. New Delhi: Sterling Publishers Private Limited.

[5]. Moughtin, C., Taner, O. C., \& Tiesdell, S. [1999], Urban Design Ornament and Decoration. Oxford: Reed Educational and Professional Ltd.

[6]. http://rachel.worldpossible.org/modules/wikipedia_for_ schools/wp/b/Buddhism.htm

[7]. https://www.flickr.com. [2009, March 24]. Retrieved January 31, 2015, from UNESCO-worldheritagesites-india:

[8]. http://www.4gress.com/sights/entry/100523.html

[9]. http://oldpicturesandpostcards.blogspot.in. [2013, 03], Retrieved January 28, 2015, from Old pictures and postcards [10]. Martin, J. [1995]. International Buddhist Door, Retrieved January 31, 2015, from

http://newlotus.buddhistdoor.com:

http://newlotus.buddhistdoor.com/en/news/d/35661

[11]. http://www.travelportalofindia.com. [2012, 06]. Retrieved January 27, 2015, from Travelportalofindia: http://www.travelportalofindia.com/2012/06/visakhapatnam/ [12]. http://newlotus.buddhistdoor.com. [2013, September 7]. Retrieved January 27, 2015, from Buddhistdoor: http://newlotus.buddhistdoor.com/en/news/d/35661

[13]. http://www.southerntravelsindia.com. [2010]. Retrieved January 25, 2015, from Southern Travels India: http://www.southerntravelsindia.com/Holiday-PackagesItinerary-Mumbai-Shirdi-Aurangabad-Ajanta-Ellora_43

[14]. http://www.carpediemresidency.com. [2014, July 24]. Retrieved January 24, 2015, from Carpediem Residency: http://www.carpediemresidency.com/gallery/

[15]. http://rachel.worldpossible.org. [2010], Retrieved december 31, 2014, from http://rachel.worldpossible.org/modules/wikipedia_for_scho ols/wp/b/Buddhism.htm

[16]. http://www.veethi.com. [2012]. Retrieved January 28, 2015, from http://www.veethi.com/tadikonda/PL69160 [17]. http://www.thehindu.com. [2010, September 9]. Retrieved January 27, 2015, from The Hindu: http://www.thehindu.com/todays-paper/tp-national/tpandhrapradesh/buddhist-site-leaves-monksawestruck/article622161.ece

\section{BIOGRAPHIES}

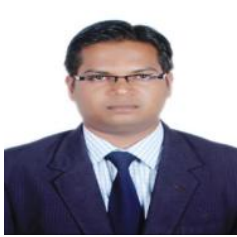

Ar. Partha Sarathi Mishra, $\mathrm{He}$ is working as Asst. Prof. in School of Architecture GITAM University; previously he has done his Master in Architecture in IIT, Roorkee. He has done his master's thesis in "Shape and Geometry of Orissan Temple Architecture". He has a keen interest to exploring the lost architectural elements in terms of design and planning issues and their hidden geometrical aspects.

Ph No: +91 83328 45448parthaconcept@gmail.com 
Ar. Ravindra Patnayaka, $\mathrm{He}$ is working as Asst. Prof. in School of Architecture GITAM University; previously he has done his Master in Planning at JNAFAU, Hyderabad. His research focuses on integrating Urban Design and Architectural elements through empirical solutions.

Ph No: +919985503512

rpdesigndesk@gmail.com 